\title{
Altered Peptidase Activities in Thyroid Neoplasia and Hyperplasia
}

\author{
Gorka Larrinaga, ${ }^{1,2,3}$ Lorena Blanco, ${ }^{2,3}$ Peio Errarte, ${ }^{2,3}$ Maider Beitia, ${ }^{2,3}$ \\ Begoña Sanz, ${ }^{2,3}$ Itxaro Perez, ${ }^{1,2,3}$ Amaia Irazusta, ${ }^{1,3}$ Clara E. Sánchez, ${ }^{1}$ \\ Francisco Santaolalla, ${ }^{4}$ Leire Andrés, ${ }^{3,5}$ and José I. López ${ }^{3,5}$ \\ ${ }^{1}$ Department of Nursing I, University School of Nursing, University of the Basque Country, P.O. Box 699, 48080 Bilbao, Bizkaia, Spain \\ ${ }^{2}$ Department of Physiology, Faculty of Medicine and Dentistry, University of the Basque Country, Bilbao, Spain \\ ${ }^{3}$ BioCruces Research Institute, Spain \\ ${ }^{4}$ Department of Otolaryngology, Basurto University Hospital, Bilbao, Spain \\ ${ }^{5}$ Department of Anatomic Pathology, Cruces University Hospital, Barakaldo, Bizkaia, Spain
}

Correspondence should be addressed to Gorka Larrinaga; gorka.larrinaga@ehu.es

Received 1 July 2013; Revised 29 September 2013; Accepted 1 October 2013

Academic Editor: Dinesh Kumbhare

Copyright (C) 2013 Gorka Larrinaga et al. This is an open access article distributed under the Creative Commons Attribution License, which permits unrestricted use, distribution, and reproduction in any medium, provided the original work is properly cited.

Background. Papillary thyroid carcinoma (PTC), follicular thyroid adenoma (FTA), and thyroid nodular hyperplasia (TNH) are the most frequent diseases of the thyroid gland. Previous studies described the involvement of dipeptidyl-peptidase IV (DPPIV/CD26) in the development of thyroid neoplasia and proposed it as an additional tool in the diagnosis/prognosis of these diseases. However, very little is known about the involvement of other peptidases in neoplastic and hyperplastic processes of this gland. Methods. The catalytic activity of 10 peptidases in a series of 30 PTC, $10 \mathrm{FTA}$, and $14 \mathrm{TNH}$ was measured fluorimetrically in tumour and nontumour adjacent tissues. Results. The activity of DPPIV/CD26 was markedly higher in PTC than in FTA, TNH, and nontumour tissues. Aspartyl aminopeptidase (AspAP), alanyl aminopeptidase (AlaAP), prolyl endopeptidase, pyroglutamyl peptidase I, and aminopeptidase B activities were significantly increased in thyroid neoplasms when compared to nontumour tissues. AspAP and AlaAP activities were also significantly higher in PTC than in FTA and TNH. Conclusions. These data suggest the involvement of DPPIV/CD26 and some cytosolic peptidases in the neoplastic development of PTC and FTA. Further studies will help to define the possible clinical usefulness of AlaAP and AspAP in the diagnosis/prognosis of thyroid neoplasms.

\section{Introduction}

Solitary and multiple nodules of the thyroid gland are very common in clinical practice, with most of them being benign lesions, either thyroid nodular hyperplasia (TNH) or follicular thyroid adenoma (FTA). Roughly only 5\% of thyroid nodules are malignant [1] and $70 \%$ of them are papillary thyroid carcinomas (PTC) [2]. The arrival of ultrasound examination to routine practice has discovered a large amount of nonpalpable and clinically silent thyroid nodules. TNH, FTA, and PTC can be distinguished from each other following well-established histopathologic criteria [3]. Interestingly, these lesions are able to be sampled with recognized diagnostic success by sonographically guided fine needle aspiration cytology [1] or by core biopsy [4].

TNH consists of multiple nodules of variable size composed of odd-shaped thyroid follicles with homogeneous bland cytology and partial encapsulation that may reverse and dissapear when the hormonal stimulus ceases. Thyroid hyperfunction is common.

FTA usually appears as asymptomatic solitary nodules. This lesion is composed of small size follicles lying in a fibrous, sometimes edematous stroma and shows a well defined fibrous capsule. There is no evidence of vascular or capsular invasion in these neoplasms; otherwise, the lesion is considered carcinoma [3]. 
PTC is the most common type of endocrine cancer and shows a varied clinical presentation. Most patients present with a thyroid nodule when they consult for the first time, but some others do not, and lymph node metastases in the neck are the sole manifestation of a tumor that remains occult in the thyroid. Histologically, PTC may display very different growth patterns $[5,6]$, and its diagnosis relies on the identification of characteristic nuclear features, such as nuclear enlargement, nuclear membrane irregularities, peripheral chromatin margination, and prominent micronucleoli [3].

Immunohistochemical markers like HBME-1, cytokeratin 19, and galectin-3 may be of help in difficult cases [6].

Bioactive peptides are regulated through specific peptidases that hydrolyze them. These peptide-converting enzymes are distributed in the main human tissues and have been originally considered to be only involved in protein and peptide scavenging [7]. However, many studies have shown that they are involved in several physiological functions and play a key role in growth control, differentiation, and signal transduction of many cell systems by modulating the activity of bioactive peptides, degrading extracellular matrix, acting as adhesion molecules and directly participating in the intracellular signaling [7-10]. So, altered expression and catalytic function patterns of these enzymes may contribute to several disease processes, including neoplastic transformation and tumour progression [8-10].

Increased understanding of the underlying pathophysiology of thyroid tumours has led to implicate several proteases in its genesis, growth, and dissemination [11-16]. Metalloproteases such as MMP-2 and 9 and peptidases such as dipeptidyl-peptidase IV/CD26 (DPPIV/CD26) change their expression and activity in these neoplasms and have been recognized as molecular markers in the diagnosis of thyroid tumours [11-18]. However, very little is known about the activity pattern of other peptidases in thyroid neoplastic and hyperplastic diseases.

This study intends to analyse the activity of different peptidases in PTC, FTA, and TNH and in the adjacent nontumour thyroid tissue, as we have performed before in other neoplasms, such as renal, colorectal and head and neck tumours [19-23]. For such a purpose, we have analyzed in these lesions the activity of 10 acid, basic, neutral, and omega peptidases covering the whole spectrum of peptideconverting activity. On the one hand, we selected five cellsurface peptidases-DPPIV/CD26, APN/CD13, NEP/CD10, APA and CAP - which have been described as tumour markers in haematologic, kidney, skin, prostate, and gynaecologic cancers, among others [8-10, 24]. On the other, five cytosolic enzymes were selected-PEP, alaAP, AspAP, APB and PGIfor better know if these enzymes may also be involved in neoplastic development."

\section{Materials and Methods}

The authors declare that all the experiments carried out in this study comply with current Spanish and European Union legal regulations.
2.1. Tissue Specimens. Representative tissue from 30 PTC, $14 \mathrm{TNH}$ and 10 FTA and their corresponding non tumour areas were adequately sampled in fresh at the Pathology Lab within the first 30 minutes after surgical removal, immediately frozen with isopentane, and stored at $-80^{\circ} \mathrm{C}$ until the enzyme assays were performed. Personal data of the patients were appropriately encrypted to preserve the anonymous use of the selected material accomplishing with international recommendations.

2.2. Sample Preparation. Soluble and membrane-bound fractions were obtained following a modified version of Zambotti-Villela et al. [25]. Explanted tissue samples were homogenized in $10 \mathrm{mM}$ Tris- $\mathrm{HCl}$ buffer at $\mathrm{pH} 7.4$, for 30 seconds at $800 \mathrm{rpm}$ using a Heidolph PZR 50 Selecta homogenizer, and ultracentrifuged in a Centrikon T-2070 Kontron Instruments apparatus at $100,000 \times \mathrm{g}$ for $35 \mathrm{~min}$. The resulting supernatants were used to measure soluble enzyme activities: APB, AspAP, PG I, PEP and AlaAP. To avoid contamination with soluble enzymes, the resulting pellets were washed three times by suspension in $10 \mathrm{mM}$ Tris- $\mathrm{HCl}$ buffer at $\mathrm{pH} 7.4$ The pellets were then homogenized in $10 \mathrm{mM}$ Tris- $\mathrm{HCl}$ buffer at $\mathrm{pH} 7.4$, and centrifuged at low speed $(800 \times \mathrm{g})$ for $3 \mathrm{~min}$ to purify the samples. The supernatants thus obtained were used to determine membrane-bound enzyme activities: APA, APN/CD13, CAP, DPPIV/CD26, and NEP/CD10. All steps were carried out at $4^{\circ} \mathrm{C}$.

2.3. Enzyme Assays. Peptidase activities were measured by incubating samples with saturating concentrations of fluorogen-derived substrates following the method described by Yoshimoto et al. [26], Mantle et al. [27], and Silveira et al. [28]. Selected peptidases, their substrates, and the reaction conditions for each enzymatic assay are summarized in Table 1.

Alanine aminopeptidase activities (AlaAP and APN/ CD13) were measured in triplicate using Ala- $\beta$-naphthylamide as a substrate. Incubations with the specific AlaAP inhibitor puromycin $(40 \mu \mathrm{M})$ were performed in parallel to discriminate between the AlaAP and APN/ CD13 forms of total alanine aminopeptidase activity. DPPIV/ CD26 and PEP activities were assayed using H-Gly-Pro$\beta$-naphthylamide, and Z-Gly-Pro- $\beta$-naphthylamide respectively. APB (basic) and acid aminopeptidase activities (AspAP, APA) were quantified with Arg- $\beta$-naphthylamide, Asp- $\beta$-naphthylamide, and Glu- $\beta$-naphthylamide substrates, respectively. Omega peptidase (PGI) activity was measured fluorometrically using pGlu- $\beta$-naphthylamide as substrate. CAP activity was analyzed using L-cystine-di- $\beta$ naphthylamide. NEP/CD10 assay was performed by incubating samples with a saturating concentration of N-dansylD-Ala-Gly-pNO $\mathrm{N}_{2}$-Phe-Gly (DAGNPG, a dansyl derivative). These assays are based on the fluorescence of products generated from substrate hydrolysis by the enzyme.

Reactions were started by adding $30-50 \mu \mathrm{L}$ of sample to $1 \mathrm{~mL}$ of the appropriate incubation mixture depending on the enzyme and substrate analyzed as follows: AlaAP, APN/CD13, APB, PEP, and PGI activities $(50 \mathrm{mM}$ phosphate buffer at $\mathrm{pH}$ 7.4 for AlaAP, APN/CD13, and PGI activities, $\mathrm{pH} 6.5$ for APB, 
TABLE 1: Substrates and the reaction conditions for each enzymatic assay.

\begin{tabular}{lcccccccc}
\hline & Substrates & $(\mathrm{mM})$ & $\mathrm{pH}^{\mathrm{a}}$ & $\begin{array}{c}\mathrm{DTT} \\
(\mathrm{mM})\end{array}$ & $\begin{array}{c}\mathrm{EDTA} \\
(\mathrm{mM})\end{array}$ & $\begin{array}{c}\mathrm{CaCl}_{2} \\
(\mathrm{mM})\end{array}$ & $\begin{array}{c}\mathrm{NaCl}^{\mathrm{ma}} \\
(\mathrm{mM})\end{array}$ & $\begin{array}{c}\mathrm{MnCl}_{2} \\
(\mathrm{mM})\end{array}$ \\
\hline PEP (EC 3.4.21.26) & Z-Gly-Pro- $\beta$-NA & 0,125 & 7,4 & 2 & - & - & - & - \\
PGI (EC 3.4.19.3) & pGlu- $\beta$-NA & 0,125 & 7,4 & 2 & 2 & - & - & - \\
APB $^{\mathrm{b}}$ (EC 3.4.11.6) & Arg- $\beta$-NA & 0,125 & 6,5 & - & - & - & 150 & - \\
APN/CD13 $^{\mathrm{b}}$ (EC 3.4.11.2) & Ala- $\beta$-NA & 0,125 & 7,4 & 1,2 & - & - & - & - \\
AlaAP (EC 3.4.11.14) & Ala- $\beta$-NA & 0,125 & 7,4 & 1,2 & - & - & - & - \\
\hline APA (EC 3.4.11.7) & H-Glu- $\beta$-NA & 0,125 & 7,4 & 0,65 & - & 0,5 & - & - \\
AspAP (EC 3.4.11.21) & Asp- $\beta$-NA & 0,125 & 7,4 & - & - & - & - & 1 \\
DPPIV/CD26 (EC 3.4.14.5) & H-Gly-Pro- $\beta$-NA & 0,2 & 8,3 & - & - & - & - & - \\
CAP (EC 3.4.11.3) & L-Cys-di- $\beta$-NA & 0,125 & 5,9 & - & - & - & - & - \\
NEP (EC 3.4.24.11) & N-Dansyl-D-Ala-Gly-pNO -Phe-Gly & 0,125 & 7,4 & - & - & - & - & - \\
\hline
\end{tabular}

${ }^{a}$ Reaction buffers: Phosphate buffer (50 mM) was used for PEP, PGI, APB, APN/CD13, and AlaAP. Tris-HCl (50 mM) was used for APA, AspAP, DPPIV/CD26, CAP, and NEP. ${ }^{\mathrm{b}} 40 \mu \mathrm{M}$ of the AlaAP inhibitor puromycin was added; ${ }^{\mathrm{c}} 4.6 \mathrm{nM}$ of the angiotensin-converting enzyme inhibitor captopril was added.

and $0.125 \mathrm{mM}$ aminoacyl- $\beta$-naphthylamide); AspAP, APA, DPPIV/CD26, CAP, and NEP/CD10 activities (50 mM Tris$\mathrm{HCl}$ buffer at $\mathrm{pH} 7.4$ for AspAP, NEP and APA, $\mathrm{pH} 8.3$ for DPPIV/CD26, pH 5.9 for CAP, and $0.125 \mathrm{mM}$ aminoacyl- $\beta$ naphthylamide or [D]AG (pN) PG).

After $30 \mathrm{~min}$ incubation at $37^{\circ} \mathrm{C}, 1 \mathrm{~mL}$ of $0.1 \mathrm{M}$ sodium acetate buffer ( $\mathrm{pH} 4.2$ ) was added to the mixture to terminate the reaction. The released product was determined by measuring the fluorescent intensity (at $412 \mathrm{~nm}$ with excitation at $345 \mathrm{~nm}$ for $\beta$-naphthylamine and at $562 \mathrm{~nm}$ with excitation at $342 \mathrm{~nm}$ for [D]AG) with a Shimadzu RF-540 Spectrofluorophotometer. Blanks consisted of buffer (instead the sample) and the same reactives and were used to determine background fluorescence. Relative fluorescence was converted into picomoles of product using a standard curve constructed with increasing concentrations of $\beta$ naphthylamine or $[\mathrm{D}] \mathrm{AG}$.

In the case of DPPIV and PEP, to verify that the formation of $\beta$-naphthylamine was specifically due to the action of these peptidases and not due to other enzymes which could cleave the same substrates (H-Gly-Pro- $\beta$-NA by DPP8 and DPP9 and Z-Gly-Pro- $\beta$-NA by seprase), we performed inhibition assays with specific inhibitors (diprotin A for DPPIV and KYP-2047 for PEP). 87\% of the DPPIV activity was inhibited in PTC, $94 \%$ in $\mathrm{TNH}$, and $100 \%$ in $\mathrm{FTA}$ and uninvolved thyroid tissue. In the case of PEP, over $95 \%$ of the activity measured was sensitive to the inhibitor in both tumour and nontumour tissues. Therefore, we concluded that the releasing of $\beta$-naphthylamine in both cases is mainly due to DPPIV and PEP.

2.4. Protein Determination. Protein concentration of soluble and membrane-bound fractions of thyroid tissues was measured in triplicate by the Bradford method [29], using BSA $(1 \mathrm{mg} / \mathrm{mL})$ as calibrator. Results were recorded as units of peptidase (UP) per milligram of protein (1 unit of peptidase (UP) is 1 pmol of naphthylamine released per minute). Fluorogenic assays were linear with respect to hydrolysis time and protein content. Activity is expressed as pmol of product $/ \mathrm{min} / \mathrm{mg}$ protein (UP/mg protein) and reported as mean $\pm \mathrm{SE}$.

2.5. Statistical Analysis. Shapiro-Wilk test was applied to data obtained from tumor samples to know if the numbers followed a normal distribution or not. Based on this information, nonparametric Mann-Whitney and Kruskal-Wallis tests were used to detect differences between two groups and more than two groups, respectively. SPSS 19.0 software was used for the statistical analysis.

\section{Results}

Females predominated in the series: the PTC group included 6 males and 24 females (average age: 53,7 years) and the FTA 3 males and 7 females ( 35.4 years). The fourteen cases of the TNH group were all females (43.2 years).

Histopathological subtyping of the PTC group included conventional PTC (16 cases, 53,3\%), follicular variant PTC (10 cases, 33,3\%), and papillary microcarcinomas (4 cases, $13,3 \%)$. Organ confined disease (pT1/2) was detected in $80 \%$ of the cases. Six cases presented minimal extracapsular extension (pT3) and two of them regional lymph node metastasis.

Table 2 shows all the peptidase activities measured in the soluble and membrane-bound fractions of hyperplastic, neoplastic, and nontumour adjacent tissues.

The cytosolic fraction activity of AspAP, PG I, PEP, and AlaAP was significantly increased in PTC (Table 2(a)) and FTA (Table 2(b)) when compared with the adjacent nontumour tissues. APB activity was also increased in both neoplasms, although this change did not reach statistical significance in PTC. There were no significant changes in the activity of these peptidases in the TNH tissue when compared with the nonhyperplastic tissue (Table 2(c)).

The membrane-bound fraction activity of DPPIV/CD26 was markedly higher in PTC (Table 2(a)) and lower in FTA 
TABle 2: (a) Peptidase activities in papillary thyroid carcinoma (PTC) and in non neoplastic adjacent thyroid tissue. (b) Peptidase activities in follicular thyroid adenoma (FTA) and in non neoplastic adjacent thyroid tissue. (c) Peptidase activities in thyroid nodular hyperplasia (TNH) and in non neoplastic adjacent thyroid tissue. Values are means \pm SE of peptidase activity recorded as pmol of units of peptidase (UP) per milligram of protein. A value of $P \leq 0.05$ was considered statistically significant (Significant results are in bold).

(a)

\begin{tabular}{lccc}
\hline Peptidase & PTC & Non neoplastic & $P$ \\
\hline Soluble fraction & & & \\
APB & $7419 \pm 1363$ & $4259 \pm 867$ & 0.094 \\
AspAP & $\mathbf{1 3 0} \pm \mathbf{1 5}$ & $\mathbf{8 7} \pm \mathbf{1 3}$ & $\mathbf{0 . 0 3 9}$ \\
PG I & $\mathbf{2 0 6} \pm \mathbf{3 9}$ & $\mathbf{7 7} \pm \mathbf{1 8}$ & $\mathbf{0 . 0 0 8}$ \\
PEP & $\mathbf{3 8 3 6} \pm \mathbf{6 3 3}$ & $\mathbf{1 9 7 7} \pm \mathbf{4 4 9}$ & $\mathbf{0 . 0 2 6}$ \\
AlaAP & $\mathbf{8 8 1 9} \pm \mathbf{1 1 9 4}$ & $\mathbf{4 1 2 2} \pm \mathbf{1 1 1 1}$ & $\mathbf{0 . 0 0 7}$ \\
Membrane-bound fraction & & & \\
APA & $1250 \pm 280$ & $1120 \pm 258$ & 0.96 \\
APN/CD13 & $2301 \pm 538$ & $2533 \pm 516$ & 0.554 \\
CAP & $875 \pm 253$ & $665 \pm 180$ & 0.425 \\
DPPIV/CD26 & $\mathbf{4 2 7 4} \pm \mathbf{1 3 0 1}$ & $\mathbf{1 3 4 7} \pm \mathbf{2 7 8}$ & $\mathbf{0 . 0 1 7}$ \\
NEP/CD10 & $3.1 \pm 0.66$ & $1.9 \pm 0.45$ & 0.12 \\
\hline
\end{tabular}

(b)

\begin{tabular}{lccc}
\hline Peptidase & FTA & Non neoplastic & $P$ \\
\hline Soluble fraction & & & \\
APB & $\mathbf{3 7 7 2} \pm \mathbf{3 1 8}$ & $\mathbf{1 9 6 9} \pm \mathbf{2 1 0}$ & $\mathbf{0 . 0 0 1}$ \\
AspAP & $\mathbf{8 4} \pm \mathbf{7 . 2}$ & $\mathbf{5 4} \pm \mathbf{2 1}$ & $\mathbf{0 . 0 0 3}$ \\
PG I & $\mathbf{2 4 5} \pm \mathbf{2 0}$ & $\mathbf{8 5} \pm \mathbf{1 2}$ & $\mathbf{0 . 0 0 1}$ \\
PEP & $\mathbf{3 0 5 6} \pm \mathbf{3 5 9}$ & $\mathbf{1 4 8 2} \pm \mathbf{1 8 4}$ & $\mathbf{0 . 0 0 2}$ \\
AlaAP & $\mathbf{2 0 2 2} \pm \mathbf{2 0 6}$ & $\mathbf{7 9 2} \pm \mathbf{7 6}$ & $\mathbf{0 . 0 0 1}$ \\
Membrane-bound fraction & & & \\
APA & $1513 \pm 191$ & $1270 \pm 141$ & 0.247 \\
APN/CD13 & $1670 \pm 198$ & $2542 \pm 274$ & 0.105 \\
CAP & $453 \pm 48$ & $407 \pm 47$ & 0.354 \\
DPPIV/CD26 & $\mathbf{5 8 9} \pm \mathbf{8 7}$ & $\mathbf{1 7 0 0} \pm \mathbf{5 4 6}$ & $\mathbf{0 . 0 3 7}$ \\
NEP/CD10 & $3.7 \pm 0.63$ & $2.8 \pm 0.45$ & 0.643 \\
\hline
\end{tabular}

(c)

\begin{tabular}{lccc}
\hline Peptidase & TNH & Nonhyperplastic & $P$ \\
\hline Soluble fraction & & & \\
APB & $3713 \pm 688$ & $5477 \pm 721$ & 0.054 \\
AspAP & $67 \pm 4.3$ & $66 \pm 14.4$ & 0.519 \\
PG I & $73 \pm 7.8$ & $81 \pm 5.3$ & 0.687 \\
PEP & $2934 \pm 448$ & $3580 \pm 478$ & 0.295 \\
AlaAP & $1834 \pm 258$ & $2087 \pm 310$ & 0.227 \\
Membrane-bound fraction & & & \\
APA & $789 \pm 140$ & $475 \pm 87$ & 0.116 \\
APN/CD13 & $1775 \pm 329$ & $1856 \pm 243$ & 0.601 \\
CAP & $317 \pm 73$ & $394 \pm 107$ & 0.687 \\
DPPIV/CD26 & $319 \pm 44$ & $804 \pm 198$ & 0.116 \\
NEP/CD10 & $1.34 \pm 0.25$ & $1.74 \pm 0.29$ & 0.414 \\
\hline
\end{tabular}

(Table 2(c)), when compared with the reference of nontumour tissue samples. By contrast, no significant changes were found in the rest of membrane-bound activities tested. TNH tissue did not yield significant changes.

Finally, when the three thyroid lesions were compared to each other, DPPIV/CD26, AlaAP, and AspAP showed significantly higher activities in PTC than in FTA and TNH (Figure 1). There were no significant results in the remaining analyzed peptidases.

\section{Discussion}

It has been reported that expression and activity patterns of proteases, such as MMPs and peptidases, are altered in malignant tumours, suggesting their implication in tumour cell growth, local invasion, and metastases [8-10]. It has been demonstrated that MMP-2 and 9 are upregulated in the tumour tissue when compared with nontumour tissue in thyroid neoplasms, suggesting that these enzymes could have a role in thyroid neoplastic transformation $[14,15]$. These MMPs and peptidases such as DPPIV/CD26 are distinctly expressed in several thyroid neoplasms and have been proposed as useful diagnostic/prognostic thyroid tumour markers [14-18].

In the same way, we observed that several peptidase activities are selectively modified in PTC and FTA when compared with nontumour adjacent tissues. Thus, cytosolic peptidases showed higher activities in both neoplasms, whereas DPPIV/CD26 activity was markedly higher in PTC and lower in FTA. Since TNH did not show any change in peptidase activity, these results indicate a role for these peptidases in the development of thyroid neoplasia.

Interestingly, peptidase activity is distinctly modified in thyroid lesions. Some authors stress that peptidases may either promote or impede tumour development depending on the specific type of tumour or on the phase of development where the tumour is, with this way suggesting that tumour growth regulation by peptides and their converting peptidases occur in a tumour specific manner [8-10]. We have shown in previous studies selective changes in peptidase activities of different neoplasms [19-23]. For example, when those were compared with uninvolved tissues, APN/CD13 and AspAP activities were decreased in renal cell carcinomas [19] and increased in head and neck squamous cell carcinoma [20]. Even more, higher APN/CD13 activity is correlated with high grade renal cell carcinomas [19] and with worse survival of these patients [22]. An exception to the observed tendency could be PEP, whose activity is increased in most of the neoplastic tissues studied to date [23, 30-32].

Recent data show that DPPIV/CD26 is a useful marker of malignancy in thyroid pathology [16]. Previous studies had already demonstrated that this serine ectopeptidase was specifically expressed in follicular-cell derived thyroid carcinomas $[17,18]$. Some of these studies have been performed by semiquantitative cytoenzymatic methods and showed the highest activities in PTC [16-18]. Our quantitative fluorimetric assay yields similar results, showing that DPPIV/CD26 activity is markedly higher in PTC than in FTA and TNH. All 


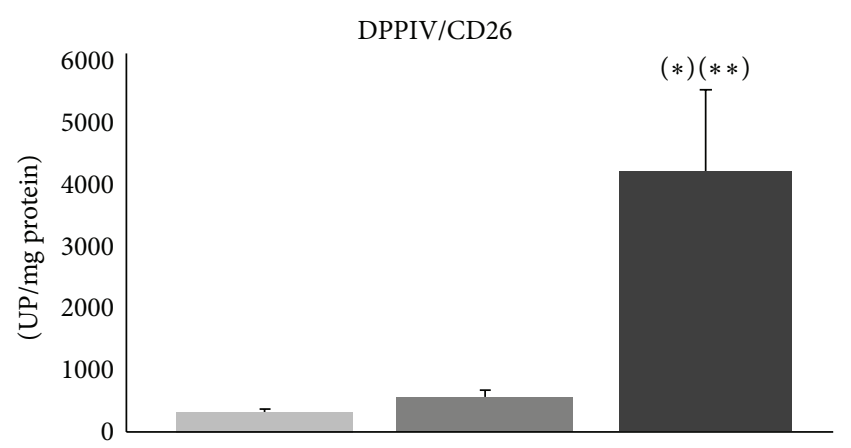

(a)

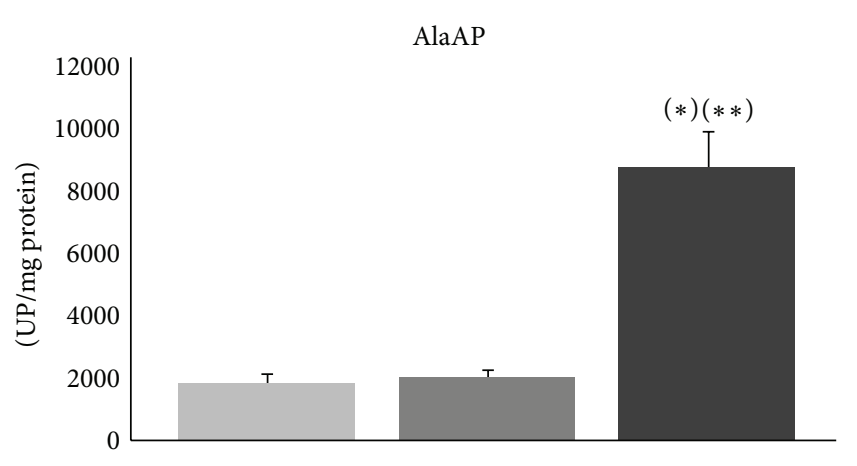

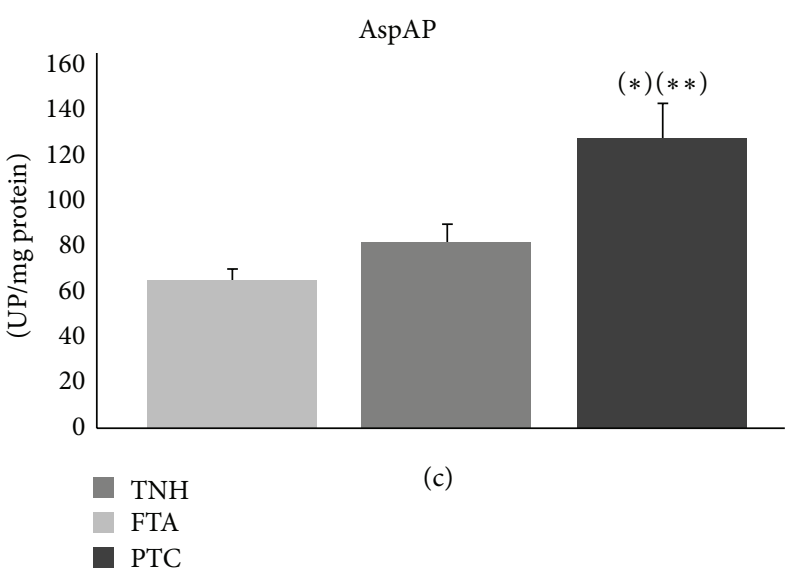

(b)

FIGURE 1: Enzymatic activities: activity in thyroid nodular hyperplasia (TNH), follicular thyroid adenoma (FTA), and papillary thyroid carcinoma (PTC) tissues. Values are means \pm SE of peptidase activity recorded as pmol of units of peptidase (UP) per milligram of protein. (a) DPPIV/CD26: a value of $P<0.05$ was considered statistically significant. ${ }^{*}$ Kruskal-Wallis test, $P \leq 0.001 .{ }^{* *}$ The activity was higher in PTC than in FTA (Mann-Whitney test, $P \leq 0.01$ ) and TNH (Mann-Whitney test, $P \leq 0.01$ ). (b) AlaAP: a value of $P<0.05$ was considered statistically significant. ${ }^{*}$ Kruskal-Wallis test, $P \leq 0.001$. $^{* *}$ The activity was higher in PTC than in FTA (Mann-Whitney test, $\left.P \leq 0.001\right)$ and TNH (Mann-Whitney test, $P \leq 0.01$ ). (c) AspAP: a value of $P<0.05$ was considered statistically significant. ${ }^{*}$ Kruskal-Wallis test, $P \leq 0.01$. ${ }^{* *}$ The activity was higher in PTC than in FTA (Mann-Whitney test, $P \leq 0.05$ ) and TNH (Mann-Whitney test, $P \leq 0.05$ ).

this accumulated experience advices that this enzyme could be considered a potential marker of practical use in thyroid cancer. Interestingly, AlaAP and AspAP are other enzymes that showed a similar pattern of activity to DPPIV in our analysis. This result opens new possibilities in the study of peptidases as thyroid tumor markers.

DPPIV/CD26 is a glycoprotein which presents wellknown pleiotropic effects, and this is probably associated with the varied roles that this enzyme shows in different neoplasms. Two main action mechanisms have been proposed: on one hand, its catalytic activity on bioactive peptides such as substance P, growth hormone-releasing hormone and several chemokines and interleukins which act in cancer growth regulation [33] and, on the other hand, through its direct interaction with certain molecules of the extracellular matrix [34]. These varied actions make it difficult to define the exact role that DPPIV/CD26 plays in cancer, and further investigations are required to elucidate them [24].

Many of the essential alterations occurring in cell physiology during carcinogenesis are mediated via extracellular cell signalling pathways that interact with intracellular circuits. So, both cell surface and intracellular molecules play pivotal roles in cancer pathobiology [35]. Several authors have pointed towards specific roles of peptidases in proliferation and neoplasia, either at the surface or at the intracellular level [36-40].

AlaAP and APB are involved in the regulation of apoptosis and cell cycle regulation, and inhibitors of these enzymes such as bestatin are potential candidates for chemotherapeutic agents [38]. On the other hand, the high activity of the cytosolic PEP in developing tissues, its cellular localization around the nucleus in proliferative cells and tumours, and the inhibition of DNA synthesis by PEP inhibitors seem to involve this enzyme in cell proliferation and differentiation [39-43]. Previous studies have also suggested a role for AspAP, PGI, and other soluble peptidases in different neoplastic processes [19-22,36]. The higher activity of these peptidases we have detected in thyroid neoplasms with respect to non neoplastic tissue points to a role of cytosolic peptidases in thyroid tumours.

The best known function of peptidases is the conversion of bioactive peptides. Aside from DPPIV/CD26, several peptides converted by cytosolic AlaAP, PEP, AspAP, and PGI are involved in cell growth and proliferative disorders [4448], for instance, angiotensins that are hydrolyzed by AspAP and PEP, opioid peptides by alaAP, leukotriene A4 by APB, and TRH, by PGI and, indirectly by PEP. However, the role of soluble peptidases in the regulation of bioactive peptides 
related to proliferative disorders is not so clear as it is in the case of cell surface peptidases. Although the secretion of PEP, APB, and other soluble peptidases into the extracellular space has been suggested as a possible peptide regulatory mechanism [49-51], there is accumulating evidence in favor of intracellular trafficking and action of certain peptides and proteolytic enzymes known as intracrine action [52-54]. Thus, it has been suggested that the aforementioned bioactive peptides may also act as intracrine factors in the intracellular space inducing cell proliferation and angiogenesis in several tissues [52-54]. Therefore, the idea of increasing cytosolic peptidase activities as a result of intracrine peptide dysregulation in thyroid neoplasms should not be ruled out.

In summary, this study analyses the activity of several peptidases in PTC, FTA, and TNH and suggests a potential role of a cell surface peptidase (DPPIV/CD26) and several cytosolic peptidases (PEP, APB, AspAP, AlaAP, and PGI) in thyroid neoplasms. However, further studies are needed to define the exact involvement of peptidases in the pathobiology of these tumours and their possible clinical usefulness.

\section{Abbreviations}

$\begin{array}{ll}\text { APA: } & \text { Aminopeptidase A } \\ \text { APN/CD13: } & \text { Aminopeptidase N/CD13 } \\ \text { AspAP: } & \text { Aspartyl aminopeptidase } \\ \text { APB: } & \text { Aminopeptidase B } \\ \text { DPPIV/CD26: } & \text { Dipeptidyl peptidase IV/CD26 } \\ \text { NEP/CD10: } & \text { Neutral endopeptidase/CD10 } \\ \text { PEP: } & \text { Prolyl endopeptidase } \\ \text { PGI: } & \text { Pyroglutamyl peptidase I } \\ \text { AlaAP: } & \text { Puromycin-sensitive alanyl aminopeptidase } \\ \text { CAP: } & \text { Cystinyl aminopeptidase } \\ \text { MMP: } & \text { Matrix metalloproteinase } \\ \text { PTC: } & \text { Papillary thyroid carcinoma } \\ \text { FTA: } & \text { Follicular thyroid adenoma } \\ \text { TNH: } & \text { Thyroid nodular hyperplasia. }\end{array}$

\section{Conflict of Interests}

The authors declare that there is no conflict of interests.

\section{Ethical Approval}

The ethic committee of the Basurto University hospital approved this study (CEIC 11/51).

\section{Acknowledgments}

The authors wish to thank Arantza Pérez (University of the Basque Country) for her technical contribution to this study. This work was supported by a Grant from the Basque Government (Saiotek SA-2010/00) and UPV/EHU (UFI 11/44).

\section{References}

[1] R. S. Bahn and M. R. Castro, "Approach to the patient with nontoxic multinodular goiter," Journal of Clinical Endocrinology and Metabolism, vol. 96, no. 5, pp. 1202-1212, 2011.
[2] J. Rosai and G. Tallini, "Thyroid gland," in Rosai and Ackerman's Surgical Pathology, vol. 1, chapter 9, pp. 487-564, ElsevierMosby, Edinburgh, UK, 10th edition, 2011.

[3] O. Mete and S. L. Asa, "Pitfalls in the diagnosis of follicular epithelial proliferations of the thyroid," Advances in Anatomic Pathology, vol. 19, no. 6, pp. 363-373, 2012.

[4] J. I. López, R. Zabala, and J. L. del Cura, "Histological diagnosis of the thyroid disease using ultrasound-guided core biopsies," European Thyroid Journal, vol. 2, pp. 29-36, 2013.

[5] R. V. Lloyd, D. Buehler, and E. Khanafshar, "Papillary thyroid carcinoma variants," Head and Neck Pathology, vol. 5, no. 1, pp. 51-56, 2011.

[6] V. A. LiVolsi, "Papillary thyroid carcinoma: an update," Modern Pathology, vol. 24, supplement 2, pp. S1-S9, 2011.

[7] M. Hallberg, P. Le Grevès, and F. Nyberg, "Neuropeptide processing," in Proteases in the Brain, U. Lendeckel and N. M. Hooper, Eds., pp. 203-234, Springer Science+Business Media, New York, NY, USA, 2004.

[8] K. Ino, K. Shibata, H. Kajiyama, F. Kikkawa, and S. Mizutani, "Regulatory role of membrane-bound peptidases in the progression of gynecologic malignancies," Biological Chemistry, vol. 385, no. 8, pp. 683-690, 2004.

[9] S. Carl-McGrath, U. Lendeckel, M. Ebert, and C. Röcken, "Ectopeptidases in tumour biology: a review," Histology and Histopathology, vol. 21, no. 12, pp. 1339-1353, 2006.

[10] C. Antczak, I. De Meester, and B. Bauvois, "Ectopeptidases in pathophysiology," Bioessays, vol. 23, no. 3, pp. 251-260, 2001.

[11] Y. Ito, H. Yoshida, K. Kakudo, Y. Nakamura, K. Kuma, and A. Miyauchi, "Inverse relationships between the expression of MMP-7 and MMP-11 and predictors of poor prognosis of papillary thyroid carcinoma," Pathology, vol. 38, no. 5, pp. 421425, 2006.

[12] Z. Kraiem and S. Korem, "Matrix metalloproteinases and the thyroid," Thyroid, vol. 10, no. 12, pp. 1061-1069, 2000.

[13] H. Liang, Y. Zhong, Z. Luo et al., "Assessment of biomarkers for clinical diagnosis of papillary thyroid carcinoma with distant metastasis," International Journal of Biological Markers, vol. 25, no. 1, pp. 38-45, 2010.

[14] H. Maeta, S. Ohgi, and T. Terada, "Protein expression of matrix metalloproteinases 2 and 9 and tissue inhibitors of metalloproteinase 1 and 2 in papillary thyroid carcinomas," Virchows Archiv, vol. 438, no. 2, pp. 121-128, 2001.

[15] I. Marecko, D. Cvejic, S. Tatic, V. Dragutinovic, I. Paunovic, and S. Savin, "Expression of matrix metalloproteinase- 2 and its tissue inhibitor-2 in fetal and neoplastic thyroid tissue and their significance as diagnostic and prognostic markers in papillary carcinoma," Cancer Biomark, vol. 11, no. 1, pp. 49-58, 2011-2012.

[16] C. De Micco, V. Savchenko, R. Giorgi, F. Sebag, and J.-F. Henry, "Utility of malignancy markers in fine-needle aspiration cytology of thyroid nodules: comparison of Hector Battifora mesothelial antigen-1, thyroid peroxidase and dipeptidyl aminopeptidase IV,' British Journal of Cancer, vol. 98, no. 4, pp. 818-823, 2008.

[17] T. Kotani, J. Kawano, T. Suganuma et al., "Immunohistochemical localization of dipeptidyl aminopeptidase IV in thyroid papillary carcinoma," International Journal of Experimental Pathology, vol. 73, no. 2, pp. 215-222, 1992.

[18] K. Umeki, T. Tanaka, I. Yamamoto et al., "Differential expression of dipeptidyl peptidase IV (CD26) and thyroid peroxidase in neoplastic thyroid tissues," Endocrine Journal, vol. 43, no. 1, pp. 53-60, 1996. 
[19] L. Blanco, G. Larrinaga, I. Pérez et al., "Acid, basic, and neutral peptidases present different profiles in chromophobe renal cell carcinoma and in oncocytoma," American Journal of Physiology, vol. 294, no. 4, pp. F850-F858, 2008.

[20] I. Pérez, A. Varona, L. Blanco et al., "Increased APN/CD13 and acid aminopeptidase activities in head and neck squamous cell carcinoma," Head and Neck, vol. 31, no. 10, pp. 1335-1340, 2009.

[21] A. Varona, L. Blanco, J. I. López et al., "Altered levels of acid, basic, and neutral peptidase activity and expression in human clear cell renal cell carcinoma," American Journal of Physiology, vol. 292, no. 2, pp. F780-F788, 2007.

[22] G. Larrinaga, L. Blanco, B. Sanz et al., "The impact of peptidase activity on clear cell renal cell carcinoma survival," American Journal of Physiology, vol. 303, no. 12, pp. F1584-F1559, 2012.

[23] G. Larrinaga, I. Perez, L. Blanco et al., "Increased prolyl endopeptidase activity in human neoplasia," Regulatory Peptides, vol. 163, no. 1-3, pp. 102-106, 2010.

[24] F. Kikkawa, H. Kajiyama, K. Shibata, K. Ino, S. Nomura, and S. Mizutani, "Dipeptidyl peptidase IV in tumor progression," Biochimica et Biophysica Acta, vol. 1751, no. 1, pp. 45-51, 2005.

[25] L. Zambotti-Villela, S. C. Yamasaki, J. S. Villarroel, R. F. Alponti, and P. F. Silveira, "Aspartyl, arginyl and alanyl aminopeptidase activities in the hippocampus and hypothalamus of streptozotocin-induced diabetic rats," Brain Research, vol. 1170, pp. 112-118, 2007.

[26] T. Yoshimoto, K. Ogita, and R. Walter, "Post-proline cleaving enzyme. Synthesis of a new fluorogenic substrate and distribution of the endopeptidase in rat tissues and body fluids of man," Biochimica et Biophysica Acta, vol. 569, no. 2, pp. 184-192, 1979.

[27] D. Mantle, B. Lauffat, J. McDermott, and A. Gibson, "Characterization of aminopeptidases in human kidney soluble fraction," Clinica Chimica Acta, vol. 187, no. 2, pp. 105-113, 1990.

[28] P. F. Silveira, J. Irazusta, J. Gil, N. Agirregoitia, and L. Casis, "Interactions among challenges of hydromineral balance, angiotensin-converting enzyme, and cystine aminopeptidase," Peptides, vol. 22, no. 12, pp. 2137-2144, 2001.

[29] M. M. Bradford, "A rapid and sensitive method for the quantitation of microgram quantities of protein utilizing the principle of protein dye binding," Analytical Biochemistry, vol. 72, no. 1-2, pp. 248-254, 1976.

[30] F. Goossens, I. De Meester, G. Vanhoof, and S. Scharpé, "Distribution of prolyl oligopeptidase in human peripheral tissues and body fluids," European Journal of Clinical Chemistry and Clinical Biochemistry, vol. 34, no. 1, pp. 17-22, 1996.

[31] J. L. Liu, M. Kusinski, V. Ilic et al., "Overexpression of the angiogenic tetrapeptide AcSDKP in human malignant tumors," Anticancer Research, vol. 28, no. 5, pp. 2813-2817, 2008.

[32] A. Sedo, E. Krepela, and E. Kasafirek, "Dipeptidyl peptidase IV, prolyl endopeptidase and cathepsin B activities in primary human lung tumours and lung parenchyma," Journal of Cancer Research and Clinical Oncology, vol. 117, no. 3, pp. 249-253, 1991.

[33] M. D. Gorrell, "Dipeptidyl peptidase IV and related enzymes in cell biology and liver disorders," Clinical Science, vol. 108, no. 4, pp. 277-292, 2005.

[34] P. Bušek, R. Malík, and A. Šedo, "Dipeptidyl peptidase IV activity and/or structure homologues (DASH) and their substrates in cancer," International Journal of Biochemistry and Cell Biology, vol. 36, no. 3, pp. 408-421, 2004.

[35] M. Grujić and M. Renko, "Aminopeptidase inhibitors bestatin and actinonin inhibit cell proliferation of myeloma cells predominantly by intracellular interactions," Cancer Letters, vol. 182, no. 2, pp. 113-119, 2002.
[36] J. M. Martínez, I. Prieto, M. J. Ramírez, C. Cueva, F. Alba, and M. Martínez, "Aminopeptidase activities in breast cancer tissue," Clinical Chemistry, vol. 45, no. 10, pp. 1797-1802, 1999.

[37] D. M. Nanus, "Of peptides and peptidases: the role of cell surface peptidases in cancer," Clinical Cancer Research, vol. 9, no. 17, pp. 6307-6309, 2003.

[38] M. W. Thompson and L. B. Hersh, "The puromycin-sensitive aminopeptidase. Role in neurological, reproductive, inmunological and proliferative disorders," in Aminopeptidases in Biology and Disease, N. M. Hooper and U. Lendeckel, Eds., pp. 1-15, Kluwer Academic/Plenum Press, New York, NY, USA, 2004.

[39] T. Ishino, S. Ohtsuki, K. Homma, and S. Natori, "cDNA cloning of mouse prolyl endopeptidase and its involvement in DNA synthesis by Swiss 3T3 cells," Journal of Biochemistry, vol. 123, no. 3, pp. 540-545, 1998.

[40] M. J. Moreno-Baylach, V. Felipo, P. T. Männistö, and J. A. García-Horsman, "Expression and traffic of cellular prolyl oligopeptidase are regulated during cerebellar granule cell differentiation, maturation, and aging," Neuroscience, vol. 156, no. 3, pp. 580-585, 2008.

[41] T. T. Myöhänen, J. I. Venäläinen, E. Tupala, J. A. GarciaHorsman, R. Miettinen, and P. T. Männistö, "Distribution of immunoreactive prolyl oligopeptidase in human and rat brain," Neurochemical Research, vol. 32, no. 8, pp. 1365-1374, 2007.

[42] M. J. Hannula, P. T. Männistö, and T. T. Myöhänen, "Sequential expression, activity and nuclear localization of prolyl oligopeptidase protein in the developing rat brain," British Journal of Pharmacology, vol. 166, no. 3, pp. 1097-1113, 2012.

[43] M. J. Moreno-Baylach, K. A. Puttonen, J. Tenorio-Laranga et al., "Prolyl endopeptidase is involved in cellular signalling in human neuroblastoma SH-SY5Y cells," NeuroSignals, vol. 19, no. 2, pp. 97-109, 2011.

[44] R. N. DuBois, "Leukotriene A4 signaling, inflammation, and cancer," Journal of the National Cancer Institute, vol. 95, no. 14, pp. 1028-1029, 2003.

[45] X. Chen, N. Li, S. Wang et al., "Leukotriene A4 hydrolase in rat and human esophageal adenocarcinomas and inhibitory effects of bestatin," Journal of the National Cancer Institute, vol. 95, no. 14, pp. 1053-1061, 2003.

[46] E. I. Ager, J. Neo, and C. Christophi, "The renin-angiotensin system and malignancy," Carcinogenesis, vol. 29, no. 9, pp. 16751684,2008 .

[47] A. Malaguti, C. Della Casa, S. Castorina et al., "Molecular mechanisms for pituitary thyrotroph cell growth," Journal of Endocrinological Investigation, vol. 27, no. 6, pp. 151-167, 2004.

[48] I. S. Zagon, M. F. Verderame, and P. J. McLaughlin, "The biology of the opioid growth factor receptor (OGFr)," Brain Research Reviews, vol. 38, no. 3, pp. 351-376, 2002.

[49] A. Balogh, S. Cadel, T. Foulon et al., "Aminopeptidase B: a processing enzyme secreted and associated with the plasma membrane of rat pheochromocytoma (PC12) cells," Journal of Cell Science, vol. 111, no. 2, pp. 161-169, 1998.

[50] J. A. García-Hornsman, P. T. Männistö, and J. I. Venäläinen, "On the role of prolyl oligopeptidase in health and disease," Neuropeptides, vol. 41, no. 1, pp. 1-24, 2007.

[51] C. N. Shrimpton, A. I. Smith, and R. A. Lew, "Soluble metalloendopeptidases and neuroendocrine signaling," Endocrine Reviews, vol. 23, no. 5, pp. 647-664, 2002.

[52] R. N. Re and J. L. Cook, "An intracrine view of angiogenesis," BioEssays, vol. 28, no. 9, pp. 943-953, 2006. 
[53] R. N. Re and J. L. Cook, "The intracrine hypothesis: an update," Regulatory Peptides, vol. 133, no. 1-3, pp. 1-9, 2006.

[54] R. N. Re and J. L. Cook, "Noncanonical intracrine action," Journal of the American Society of Hypertension, vol. 5, no. 6, pp. 435-448, 2011. 


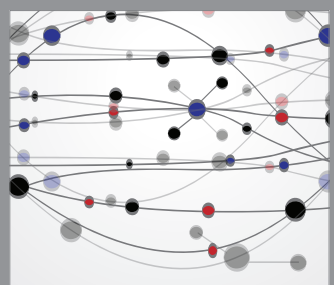

The Scientific World Journal
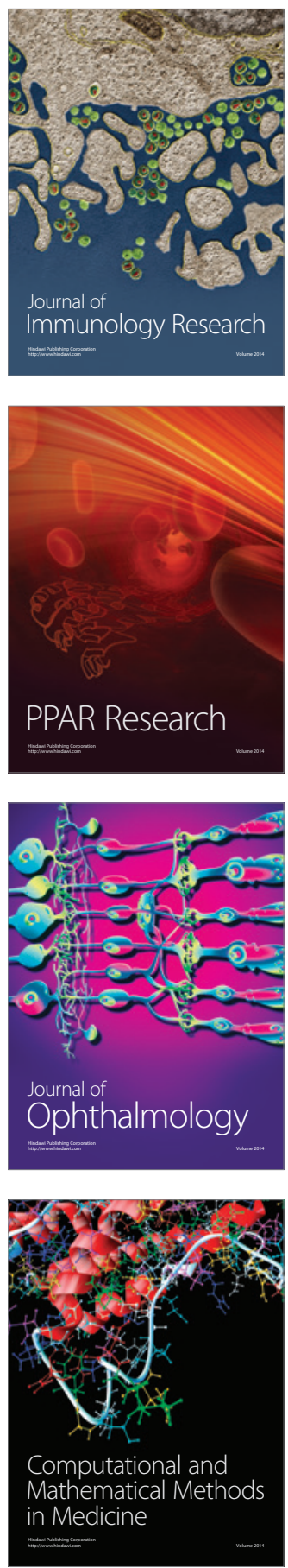

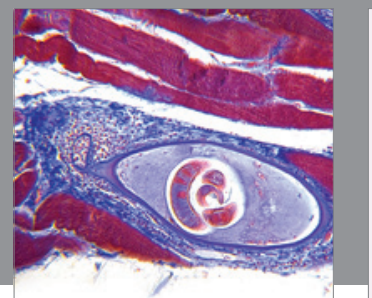

Gastroenterology

Research and Practice
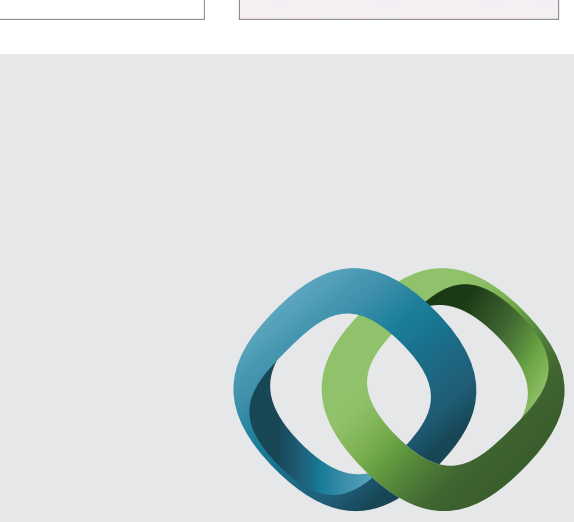

\section{Hindawi}

Submit your manuscripts at

http://www.hindawi.com
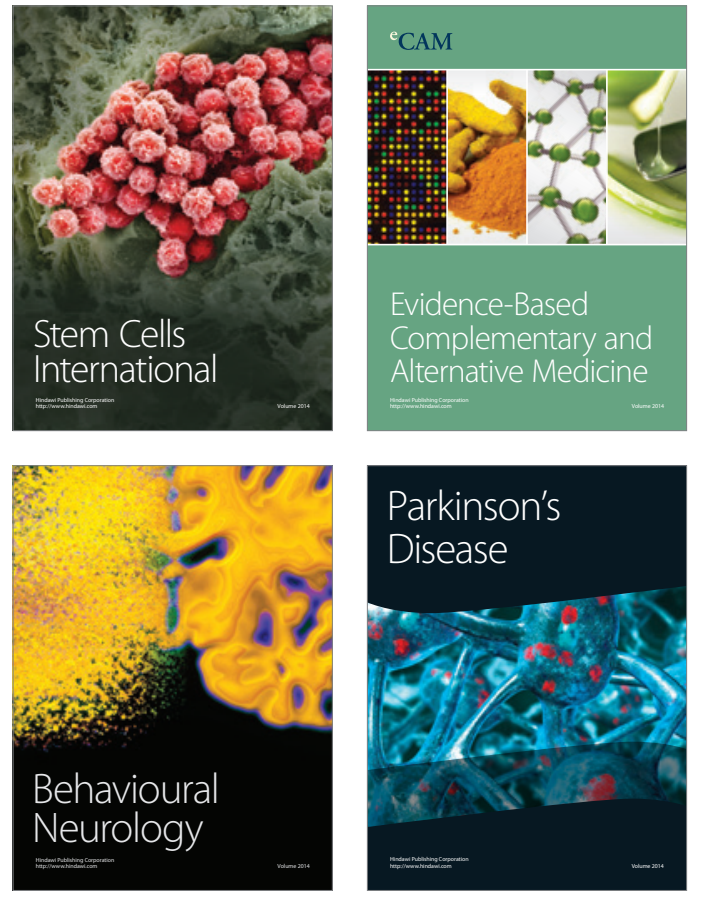
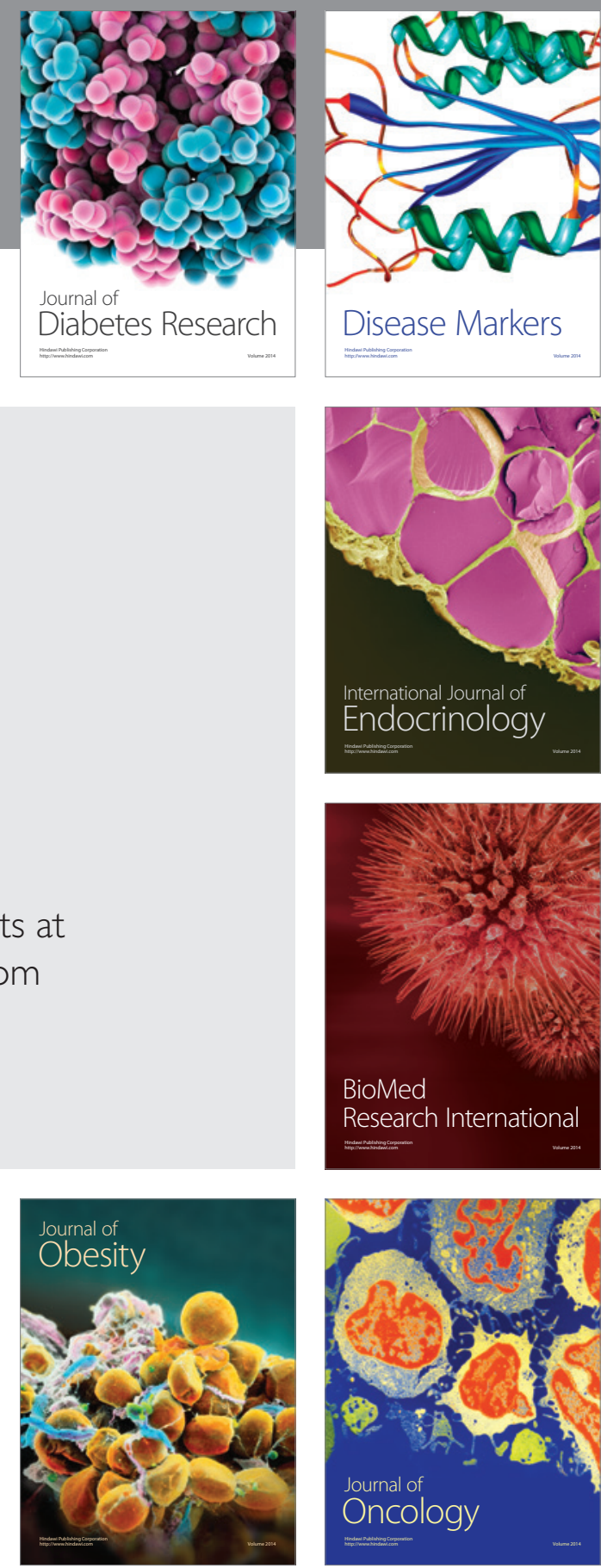

Disease Markers
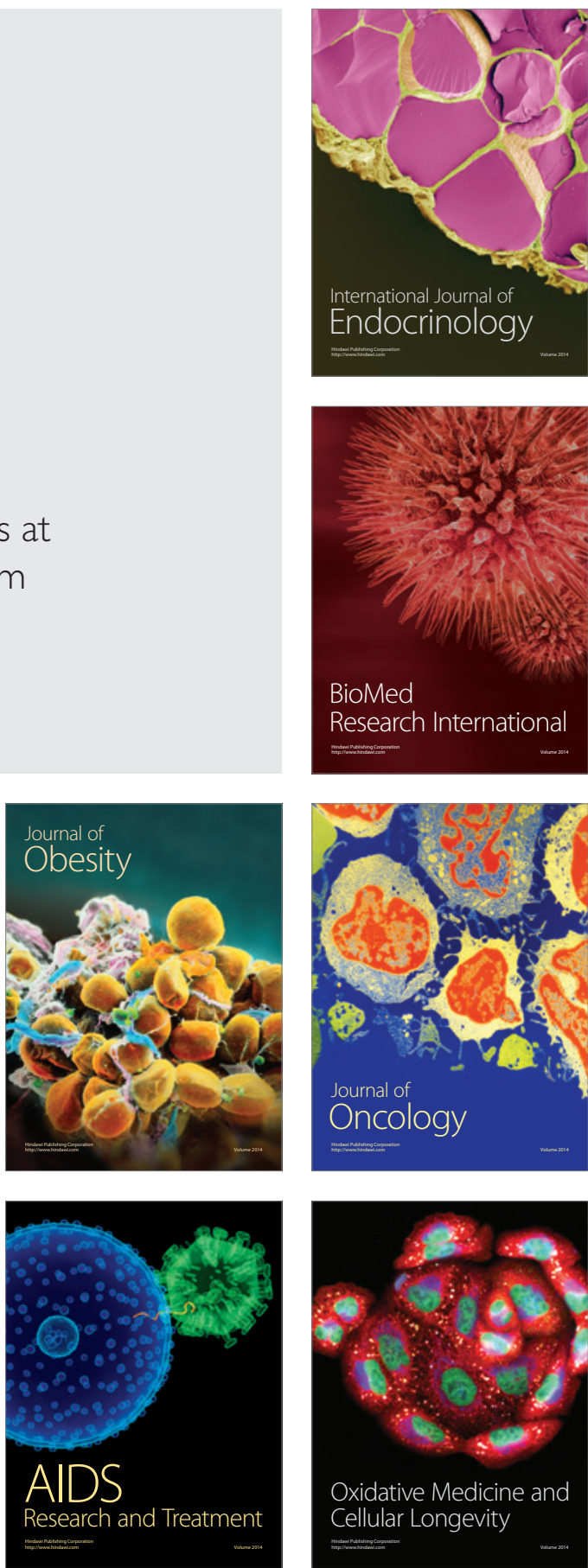